\title{
SELECTION EXPERIMENTS ON MELANISM IN AMATHES GLAREOSA ESP. (LEPIDOPTERA)
}

\author{
H. B. D. KETTLEWELL
}

Genetics Laboratory, Department of Zoology, University of Oxford

\section{INTRODUCTION}

Received I5.iv.6I

THE Noctuid moth Amathes glareosa Esp. is widely distributed throughout the Shetland Isles (Kettlewell and Berry, I96I). It has been established that at the north end of the islands 97 per cent. of the population are of the melanic form edda. By contrast on south Shetland Mainland, less than 6o miles away, the population is $9^{8}$ per cent. of the light form. In the intervening region there is a steady frequency cline which is interrupted by a rather rapid change near the Tingwall Valley, which appears to act as a partial barrier. Fuller details of the two contrasting populations to the north and to the south must be recorded here.

\section{THE STRUCTURES OF THE TWO POPULATIONS}

\section{(i) Unst, North Shetland}

In 1959 a total of 2539 A. glareosa were examined by C. J. Cadbury. Of these 77 were $f$. typica $(3.03$ per cent.). This sample was smaller than that taken in 1960 , because of an insufficient number of mercury vapour traps on which we depend for sampling. The total captures in each of these years, therefore, bears no direct relationship to the abundance of the species.

In 1960 10,650 $A$. glareosa were caught of which 294 were $f$. typica ( 2.76 per cent.) (text-fig. I). In the first week 90 per cent. of the $A$. glareosa were males but at the end of the season a higher proportion were females. Table I shows nightly catches for the season along with the percentage of $f$. typica. There is some evidence that the frequency of $f$. typica in the north increases throughout the hatching period. This will be discussed later.

\section{(ii) Dunrossness, South Mainland}

The structure of the population is very different here. Of $5013 A$. glareosa which were captured in $1960,49^{1} 3$ were $f$. typica ( $9^{8}$ per cent.). There was no evidence that $f$. edda appeared earlier than $f$. typica in these figures, nor would it be expected if predation is relaxed in south Shetland, since there would then be no selection in favour of the later emergence of either form.

This situation of two contrasting populations appeared to offer exceptional opportunities for analysis by experimentation in the field. With the help of a team already trained in the special techniques, I decided to undertake extensive mark-release-recapture experiments both in north and south Shetland, the two to run concurrently. By 
choosing the opposite ends of the Shetland Isles as centres of our experimental releases where the frequencies of the two forms showed their greatest contrasts, I had hoped to be able to evaluate the results of selective predation in the same way as had been possible in industrial melanism. The method employed was to catch and mark large numbers of each form at both locations. A proportion of the commoner

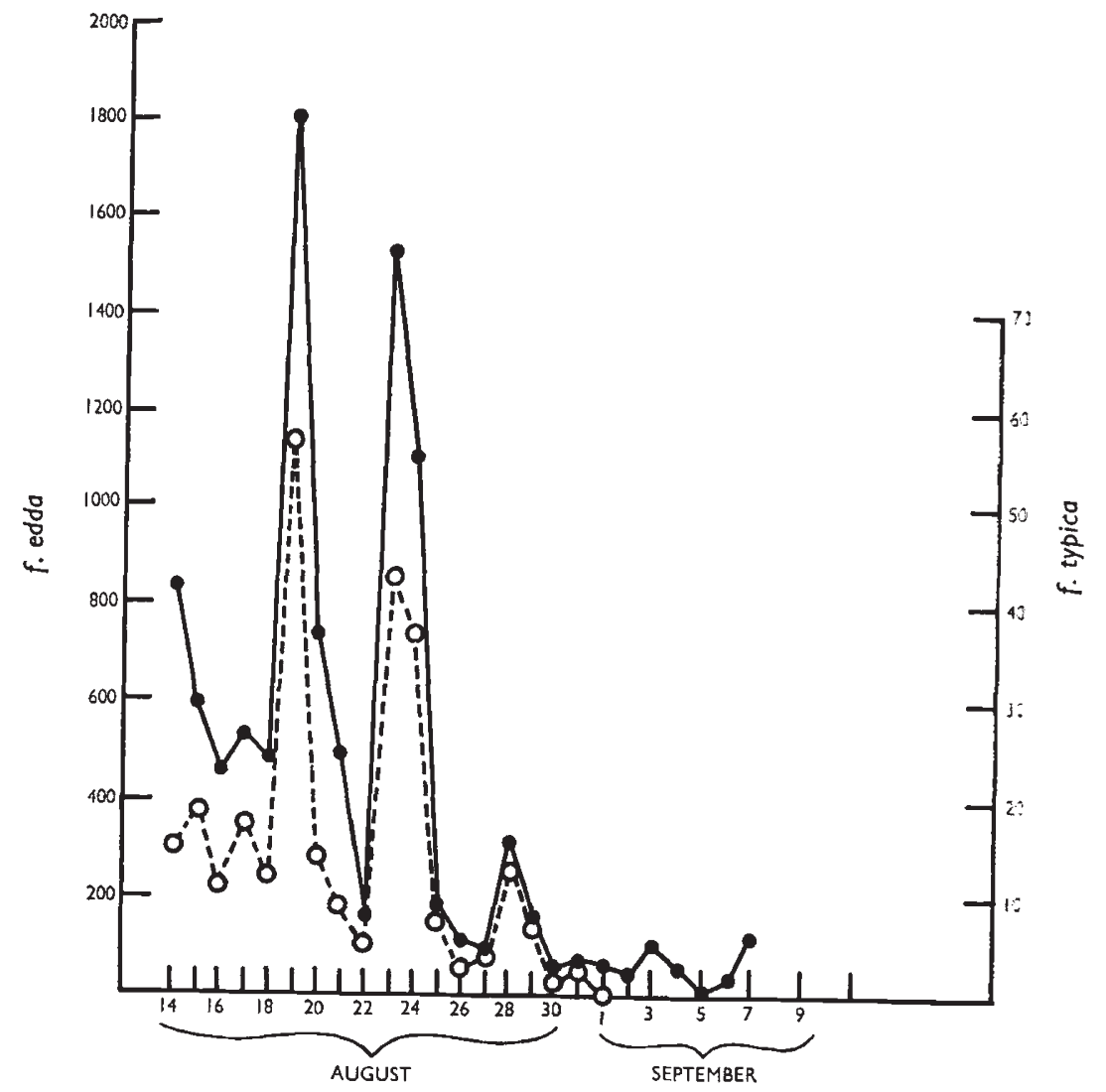

TEXT-FIG. 1.-Wild captures of the two forms of Amathes glareosa taken in mercury vapour traps, Unst 1960 (continuous line $f$. edda).

of the two forms was then transported as rapidly as possible to the opposite end of the islands. In view of the fact that the distances involved were small, it has been assumed that each phenotype, regardless of origin, was identical with another of the same form in regard to its behaviour. Further work will confirm or deny this.

Unfortunately in carrying out a design of experiment as complicated as this we met with considerable difficulty. There are two sounds to be negotiated, firstly between the islands of Unst and Yell, and secondly between Yell and north Shetland Mainland. Nevertheless, with the collaboration of the Shetlanders, a parcel of live insects was sent each day from north to south and another from south to north. This demanded the daily use of four separate omnibus services and two 
ferries in each direction. The specimens were contained in pill boxes, 2 in a box, and it is fair to the Shetlanders to put on record that on no single occasion were any of the 44 parcels either damaged or lost. All the moths arrived in excellent condition and by this means we had a plentiful supply of the rarer of the two forms at each of the opposing centres of mark-release. Because of the journey, however, 36 hours elapsed between the catching of the moths and their subsequent release. We were punctillious throughout therefore to ensure that the locally caught specimens were similarly incarcerated for $3^{6}$ hours, 2 to each pill box. This shuttle service continued daily (except Sunday) from I4th August till $5^{\text {th }}$ September.

\section{MARKING AND RELEASING TECHNIQUES}

Marking techniques were modelled on those devised by Dowdeswell, Fisher and Ford (I940). I have previously used modifications of these on a number of Lepidopteran species with satisfactory results. $A$. glareosa, however, presented particular difficulties. A small scuttling Noctuid moth, whose hindwings project almost as far as the forewings, and which at the same time are plicated like a fan, was found to be very different from those species with which I have previously worked. The lethargy of Biston betularia, the surface area of Lasiocampa quercus, and the convenient white spotting of Panaxia dominula were all absent. Nevertheless we eventually developed a technique for successful marking without the use of an anæsthetic which at one time we thought would be necessary. This depended on a method of handling the moth with forceps in such a way that the wings were dorsi-flexed and ensuring that they were not stuck together after applying the paint spot.

Using a combination of the undersides of four wings, and five colours, we were able to identify twenty individual markings, and we found this adequate for the life-span of the species. In I959 a small pilot experiment had been undertaken on Unst (Site I), but because of an inadequate knowledge of the natural history of the moth, an insufficient supply of $f$. typica from south Shetland was available. In I 960 we commenced mark-release experiments on the same releasing site (Site I), but this was abandoned after three days because, unlike I959, there was no evidence of birds feeding in the area. The new site chosen (Site 2) was separated from the first by a half-mile stretch of sea. It was situated on the side of the hill of Muckle Heog to the north of Baltasound. Geologically this area consists of serpentine rock and as such is a specialised biotope maintaining many rare species of small plants (Spence, 1957). Due to the toxic nature of the soil the vegetation is sparse and the peat-coloured soil is shallow, though no depth of peat is present.

On our first visit in 1959 we arrived on Ist August. Subsequently we found $A$. glareosa extremely common here. Furthermore, birds were active on the ground not only by day but throughout most of the night. After mid-August, however, the hours of darkness rapidly increase 
at this latitude, so that in 1960 when we arrived two weeks later we observed no twilight activity by birds whatever. Nor did we record any at full moon which was on $5^{\text {th }}$ September. Diurnal feeding, however, was very much in evidence on Site 2.

TABLE I

Wild population captures for Amathes glareosa and its melanic form edda, Unst, $\mathcal{N}$. Shetland, ig6o

\begin{tabular}{|c|c|c|c|c|c|}
\hline & \multirow{2}{*}{ Date } & \multicolumn{2}{|c|}{ Phenotype } & \multirow{2}{*}{ Total } & \multirow{2}{*}{ Per cent. typica } \\
\hline & & Typica & $E d d a$ & & \\
\hline Site I & $\begin{array}{l}13.8 .60 \\
14.8 .60 \\
15.8 .60 \\
16.8 .60 \\
17.8 .60 \\
18.8 .60\end{array}$ & $\begin{array}{l}0 \\
15 \\
19 \\
19 \\
18 \\
12\end{array}$ & $\begin{array}{r}3 \\
835 \\
611 \\
465 \\
629 \\
485\end{array}$ & $\begin{array}{r}3 \\
850 \\
630 \\
476 \\
647 \\
497\end{array}$ & $\begin{array}{l}\ldots \\
1 \cdot 765 \\
3.016 \\
3 \cdot 311 \\
2 \cdot 782 \\
2 \cdot 415\end{array}$ \\
\hline \multirow[t]{2}{*}{ Site 2} & $\begin{array}{l}19.8 .60 \\
2.8 .60 \\
21.8 .60 \\
22.8 .60 \\
23.8 .60 \\
24.8 .60 \\
25.8 .60 \\
26.8 .60 \\
27.8 .60 \\
28.8 .60 \\
29.8 .60 \\
30.8 .60 \\
31.8 .60 \\
1.9 .60 \\
2.9 .60 \\
3.9 .60 \\
4.9 .60 \\
5.9 .60 \\
6.9 .60 \\
7.9 .60 \\
8.9 .60\end{array}$ & $\left.\begin{array}{r}54 \\
14 \\
9 \\
6 \\
43 \\
37 \\
7 \\
3 \\
4 \\
13 \\
7 \\
3 \\
5 \\
0 \\
1 \\
4 \\
2 \\
0 \\
4 \\
2 \\
1\end{array}\right\}-14$ & $\begin{array}{r}\mathrm{I}, 792 \\
743 \\
484 \\
166 \\
\mathrm{I}, 530 \\
\mathrm{I}, 1 \mathrm{II} \\
225 \\
110 \\
88 \\
320 \\
160 \\
58 \\
68 \\
6 \mathrm{I} \\
4 \mathrm{I} \\
99 \\
54 \\
5 \\
30 \\
121 \\
62\end{array}$ & $\left.\begin{array}{r}1,846 \\
757 \\
493 \\
172 \\
1,573 \\
1,148 \\
232 \\
113 \\
92 \\
333 \\
167 \\
61 \\
73 \\
61 \\
42 \\
103 \\
56 \\
5 \\
34 \\
123 \\
63\end{array}\right\}-487$ & $\left.\begin{array}{r}2.925 \\
1.849 \\
1 \cdot 826 \\
3 \cdot 488 \\
2 \cdot 734 \\
3 \cdot 223 \\
3 \cdot 017 \\
2 \cdot 655 \\
4 \cdot 34^{8} \\
3 \cdot 904 \\
4 \cdot 192 \\
4 \cdot 918 \\
6 \cdot 849 \\
\ldots \\
2 \cdot 381 \\
3 \cdot 883 \\
3 \cdot 571 \\
\ldots \\
11 \cdot 765 \\
1 \cdot 626 \\
1 \cdot 587\end{array}\right\}-2 \cdot 875$ \\
\hline & & 294 & 10,356 & 10,650 & $2 \cdot 76 \mathrm{I}$ \\
\hline
\end{tabular}

This new releasing ground was approximately one-quarter square mile in extent and from 18 th August till $5^{\text {th }}$ September large numbers of $A$. glareosa were released daily, each form being as near to equality as possible. Because of the eccentricities of the omnibus services the release was not practicable before 4 p.m. The time available for predation on the first day was therefore limited to a few hours. After release the behaviour of both forms followed a definite pattern. Both fed for a short period on heather flowers and then took up their 


\begin{tabular}{|c|c|c|c|c|c|c|c|c|}
\hline \multirow{2}{*}{\multicolumn{2}{|c|}{ 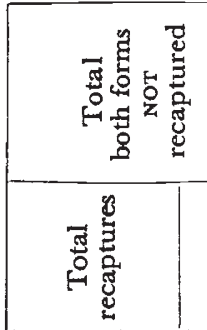 }} & & 융요 & Na & 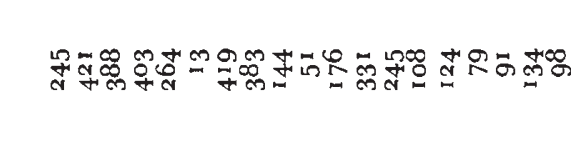 & $\Xi$ & \multirow{2}{*}{\multicolumn{2}{|c|}{ 孪 }} \\
\hline & & 노 & ond & & 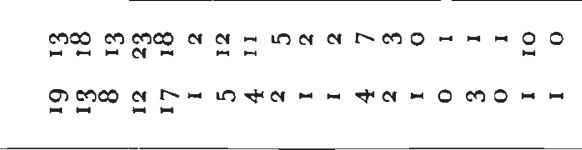 & $\stackrel{\text { के }}{2}$ & & \\
\hline \multirow{14}{*}{ 公 } & 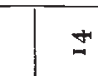 & FI & & & 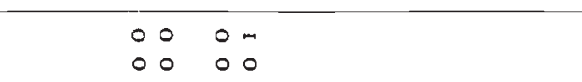 & $\ddot{0}$ & 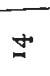 & \multirow{14}{*}{ คิ } \\
\hline & $\infty$ & tra & & & $\begin{array}{llll}0 & 0 & 0 & 0 \\
0 & 0 & 0 & 0\end{array}$ & $\begin{array}{l}0 \\
0\end{array}$ & $\stackrel{\infty}{\rightarrow}$ & \\
\hline & 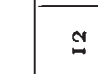 & 되 & & & $\begin{array}{llll}0 & -1 & 0 & 0 \\
0 & 0 & 0 & 0\end{array}$ & $\overline{0}$ & $\cong$ & \\
\hline & $\Xi$ & 되 & & & $\begin{array}{lllll}0 & 0 & -1 & 0 & 0 \\
-0 & 0 & 0 & 0\end{array}$ & $\overline{-}$ & $\Xi$ & \\
\hline & 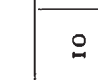 & 되 & & & $\begin{array}{llllllllllll}0 & 0 & 0 & 0 & -0 & 0 & 0 & 0 \\
0 & 0 & 0 & 0 & 0 & 0 & 0 & 0\end{array}$ & H & 임 & \\
\hline & $\sigma$ & 되 & & & $\begin{array}{lllllllll}0 & 0 & 0 & 0 & 0 & 0 & 0 & 0 & -1 \\
0 & 0 & 0 & 0 & 0 & 0 & -0 & 0 & 0\end{array}$ & $\stackrel{n}{a}$ & $\sigma$ & \\
\hline & $\infty$ & 되 & & & $\begin{array}{llllllllll}0 & 0 & -1 & 0 & 0 & -10 & 0 & 0 & 0 & 0 \\
0 & 0 & 0 & 0 & 0 & 0 & 0 & -1 & 0 & 0\end{array}$ & $\begin{array}{l}a \\
-\end{array}$ & $\infty$ & \\
\hline & r & 되 & & & $\begin{array}{llllllllll}0 & 0 & 0 & -1 & 0 & 1 & 0 & 0 & 0 & 0 \\
0 & 0 & 1 & 0 & 0 & 0 & 0 & 0 & 0 & 0\end{array}$ & $\infty$ & N & \\
\hline & 0 & 되 & & & 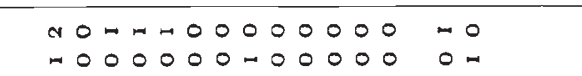 & $\stackrel{\infty}{\infty}$ & 0 & \\
\hline & n & 외 & & & 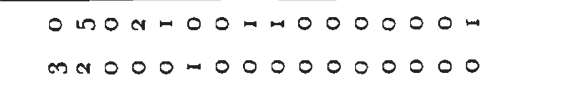 & \pm & $n$ & \\
\hline & + & 되 & & & $\begin{array}{l}0 \pi+\pi 000000-0=00-0 \\
\text { Hana }\end{array}$ & 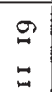 & $\dot{+}$ & \\
\hline & $\infty$ & 되 & $\begin{array}{l}0 \text { n } \\
m a\end{array}$ & & 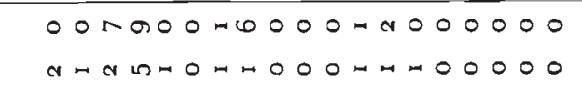 & 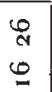 & $m$ & \\
\hline & d & 되 & or & & 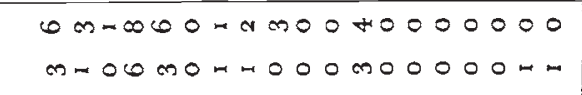 & $\begin{array}{l}\text { ले } \\
\stackrel{\text { मे }}{2}\end{array}$ & a & \\
\hline & - & 되 & $\begin{array}{l}0,4 \pi \\
0 \% a\end{array}$ & & 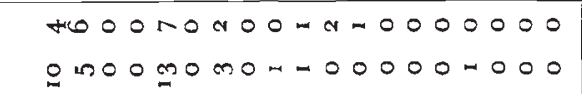 & $\begin{array}{l}\stackrel{m}{a} \\
\ddot{m}\end{array}$ & - & \\
\hline \multicolumn{2}{|r|}{ 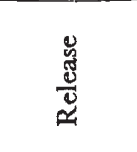 } & H & 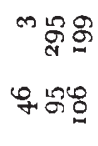 & $\begin{array}{l}\text { के } \\
\text { 辛 }\end{array}$ & 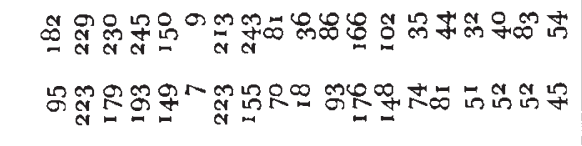 & 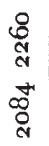 & 离 & \\
\hline \multicolumn{2}{|r|}{ 这 } & & 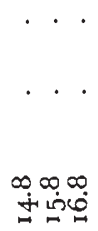 & 要 & $\begin{array}{c}\ldots \ldots \ldots \ldots \\
0 \ldots \ldots \infty\end{array}$ & . & & \\
\hline
\end{tabular}


characteristic resting positions on the ground and from then on rarely moved till dark.

Around this releasing ground and at distances of approximately 200 to 500 yards we had three concealed I25-watt mercury vapour traps. These were turned on each evening at early dusk and off at dawn. The highly successful type of trap we have now developed

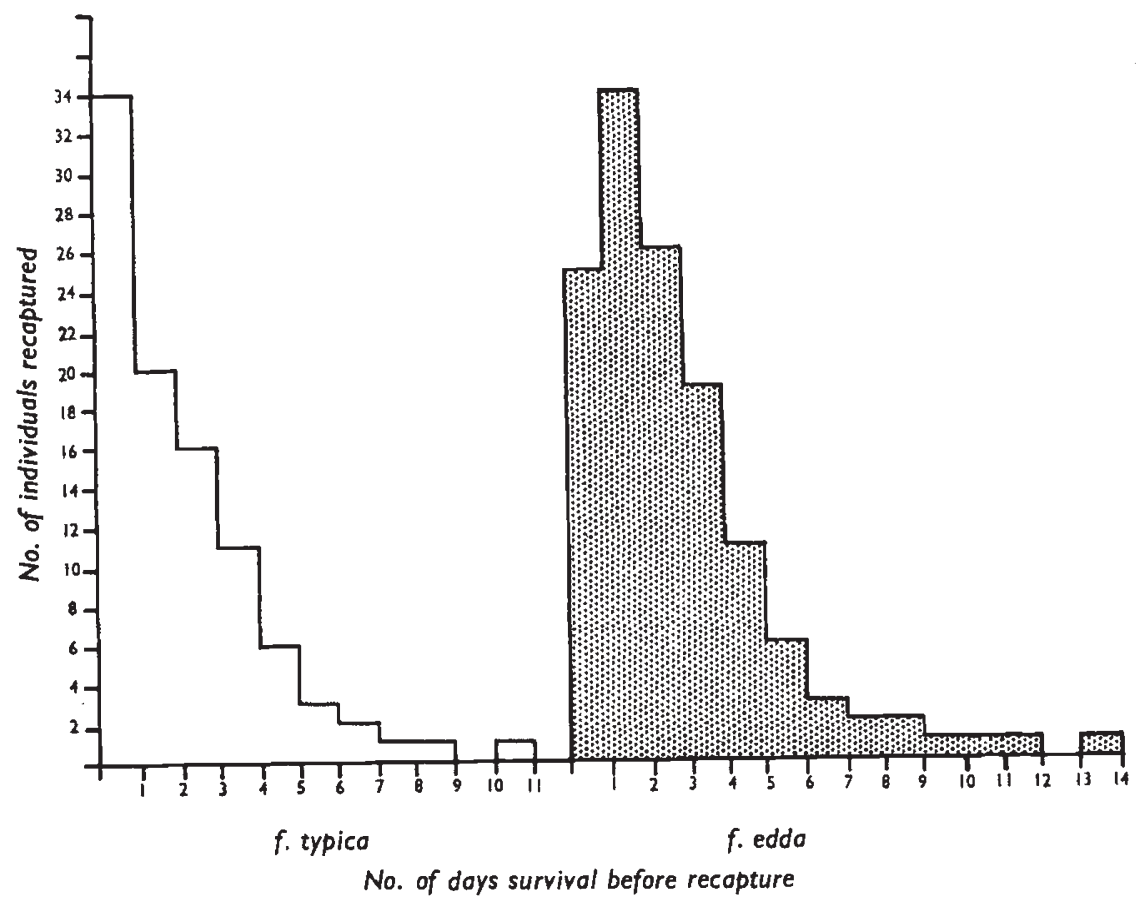

TExr-FIG. 2.-Histograms of marked recaptures of both forms of Amathes glareosa showing the number of days' survival in the wild population (from 19 separate releases), Unst 1960.

captures, we believe, random samples of the insects which are in flight. A similar design of sampling was employed at each of the releasing sites.

\section{RELEASE DATA}

We are here concerned with the recapture results of three release experiments undertaken in this way in 1960; two on Unst on north Shetland and one in the south Mainland. On Unst 90 per cent. of the $f$. typica released came from south Shetland: in Dunrossness 92 per cent. of $f$. edda were imported from Unst.

Unst Site I: Total release 744 A. glareosa (edda 497; typica 247).

This site was abandoned after three days for the reasons given above.

Unst Site 2: Total release 4344 A. glareosa (edda 2260; typica 2084). Dunrossness, south Shetland: Total release 2144 A. glareosa (edda 96r; typica I 183 ).

Tables 2 and 3 show the distribution of subsequent recaptures and text-fig. 2 depicts the histograms of recaptures of each form from Unst 
SELECTION FOR MELANISM

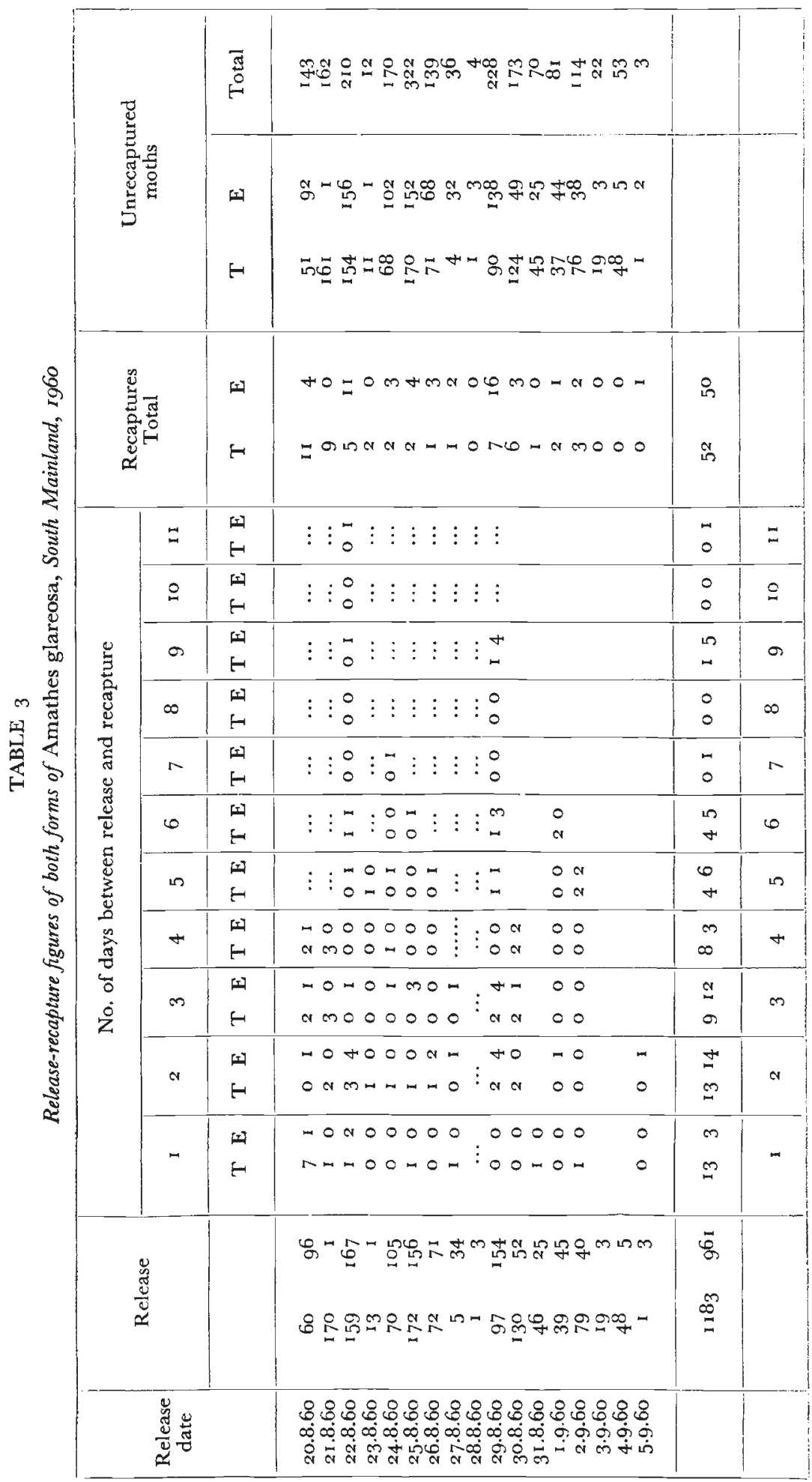


TABLE 4

Observed and expected recaptures of both forms of Amathes glareosa for day I, day 2 and for the total period, together with variance

\begin{tabular}{|c|c|c|c|c|c|c|c|c|c|}
\hline \multirow{2}{*}{$\begin{array}{l}1960 \\
\text { North End Site I } \\
\text { (Unst, Shetland) }\end{array}$} & \multicolumn{3}{|c|}{ Day I } & \multicolumn{3}{|c|}{ Day 2} & \multicolumn{3}{|c|}{$\begin{array}{l}\text { Total recaptures } \\
\text { all days }\end{array}$} \\
\hline & $\begin{array}{l}\text { Obs. } \\
\text { edda }\end{array}$ & $\begin{array}{l}\text { Exp. } \\
\text { edda }\end{array}$ & Var. & $\begin{array}{l}\text { Obs. } \\
\text { edda }\end{array}$ & $\begin{array}{l}\text { Exp. } \\
\text { edda }\end{array}$ & Var. & $\begin{array}{l}\text { Obs. } \\
\text { edda }\end{array}$ & $\begin{array}{l}\text { Exp. } \\
\text { edda }\end{array}$ & Var. \\
\hline $\begin{array}{l}\text { 14th August } \\
\text { 15th } \\
\text { 16th }\end{array}$ & $\begin{array}{l}0 \\
0 \\
2\end{array}$ & $\begin{array}{l}\ldots \\
1 \cdot 513 \\
1 \cdot 957\end{array}$ & $\begin{array}{l}\cdots .368 \\
0.3676\end{array}$ & $\begin{array}{l}\mathrm{o} \\
4 \\
0\end{array}$ & $\begin{array}{c}3 \ddot{8} 82 \\
\ldots\end{array}$ & $\begin{array}{l}\cdots \\
0.9^{12} \\
\cdots\end{array}$ & \multicolumn{3}{|c|}{$\begin{array}{l}\text { Site abandoned } \\
\text { after } 3 \text { days }\end{array}$} \\
\hline Total Site I & 2 & $3 \cdot 470$ & I $\cdot 044$ & 4 & $3 \cdot 7^{82}$ & 0.912 & & & \\
\hline 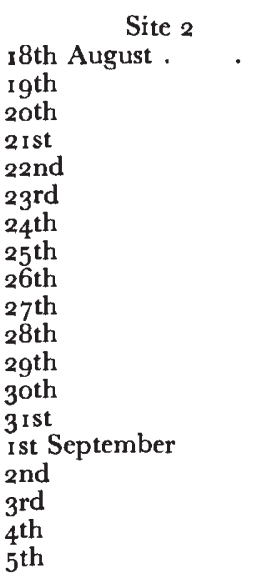 & $\begin{array}{l}4 \\
6 \\
0 \\
0 \\
7 \\
2 \\
2 \\
0 \\
0 \\
1 \\
2 \\
1 \\
0 \\
0 \\
0 \\
0 \\
0 \\
0 \\
0\end{array}$ & $\begin{array}{c}9 \cdot 199 \\
5 \cdot 573 \\
\ldots \\
\ldots \\
\mathrm{I0} \cdot 033 \\
\mathrm{I} \cdot 125 \\
2 \cdot 443 \\
\ldots \\
0 \cdot 536 \\
\mathrm{I} \cdot 353 \\
0 \cdot 96 \mathrm{r} \\
0 \cdot 485 \\
\ldots \\
\ldots \\
\ldots \\
0.386 \\
\ldots \\
\ldots \\
\ldots\end{array}$ & $\begin{array}{c}3 \cdot 006 \\
2 \cdot 689 \\
\ldots \\
\ldots \\
4 \cdot 68 \text { I } \\
0 \cdot 459 \\
1.238 \\
\ldots \\
0 \cdot 249 \\
0 \cdot 436 \\
0 \cdot 496 \\
0 \cdot 250 \\
\ldots \\
\ldots \\
\ldots \\
0 \cdot 237 \\
\ldots \\
\ldots \\
\ldots\end{array}$ & $\begin{array}{l}6 \\
3 \\
1 \\
8 \\
6 \\
0 \\
1 \\
2 \\
3 \\
0 \\
0 \\
4 \\
0 \\
0 \\
0 \\
0 \\
0 \\
0 \\
0\end{array}$ & $\begin{array}{c}5 \cdot 913 \\
2 \cdot 027 \\
0 \cdot 562 \\
7 \cdot 83^{1} \\
4 \cdot 5^{15} \\
\ldots \\
0 \cdot 977 \\
1 \cdot 83^{2} \\
\mathrm{I} \cdot 609 \\
\ldots \\
\ldots \\
3 \cdot 39^{8} \\
\ldots \\
\ldots \\
\ldots \\
\ldots \\
\ldots \\
\ldots\end{array}$ & $\begin{array}{c}\mathbf{I} \cdot 969 \\
0 \cdot 993 \\
0 \cdot 245 \\
3 \cdot 34^{8} \\
2 \cdot 190 \\
\ldots \\
0 \cdot 499 \\
0 \cdot 710 \\
0 \cdot 73^{6} \\
\ldots \\
\ldots \\
1 \cdot 718 \\
\ldots \\
\ldots \\
\ldots \\
\ldots \\
\ldots \\
\ldots \\
\ldots\end{array}$ & $\begin{array}{r}13 \\
18 \\
13 \\
23 \\
18 \\
2 \\
12 \\
11 \\
11 \\
5 \\
2 \\
2 \\
7 \\
3 \\
0 \\
1 \\
1 \\
1 \\
0 \\
0\end{array}$ & $\begin{array}{r}21 \cdot 025 \\
15 \cdot 706 \\
11.809 \\
19 \cdot 578 \\
17.559 \\
1.600 \\
8 \cdot 305 \\
9 \cdot 15^{8} \\
3 \cdot 755 \\
2 \cdot 000 \\
1 \cdot 441 \\
5.339 \\
2 \cdot 040 \\
0 \cdot 321 \\
0 \cdot 352 \\
1 \cdot 542 \\
0 \cdot 435 \\
0 \cdot 615 \\
0 \cdot 545\end{array}$ & $\begin{array}{l}6 \cdot 401 \\
7 \cdot 233 \\
4 \cdot 915 \\
7 \cdot 955 \\
7 \cdot 751 \\
0.640 \\
4 \cdot 092 \\
3 \cdot 441 \\
1 \cdot 671 \\
0 \cdot 642 \\
0 \cdot 740 \\
2 \cdot 667 \\
1 \cdot 188 \\
0 \cdot 218 \\
0 \cdot 228 \\
0.913 \\
0 \cdot 246 \\
0.237 \\
0 \cdot 248\end{array}$ \\
\hline \multirow[t]{2}{*}{ Total Site 2} & 25 & $32 \cdot 074$ & $13.74 \mathrm{I}$ & 34 & $28 \cdot 66_{4}$ & $12 \cdot 408$ & 132 & $123 \cdot 125$ & $5^{I} \cdot 4^{26}$ \\
\hline & & & & & & & \multicolumn{3}{|c|}{$\begin{aligned} \text { Diff. : } & 8 \cdot 875 \pm 7 \cdot \mathrm{I} 712 \\
& \text { (Standard error) } \\
\mathrm{I} \cdot 24= & \mathrm{P}>0.2 \mathrm{I}<0.22 \\
= & 7 \text { per cent. diff. } \\
& \text { in favour of } f . \\
& \text { edda }\end{aligned}$} \\
\hline
\end{tabular}

releases site 2. A full analysis of the south Shetland experiment is not given because both the release techniques and the site chosen were considered unsatisfactory.

\section{ANALYSIS OF RECAPTURE DATA}

On comparing the histograms of the two forms for the main release in the north, in which recaptures are recorded according to the number of days' survival of each form in the wild, two main points stand out. Firstly there is a deficiency of $f$. edda recaptures on the first day. On the other hand the histogram for $f$. typica has a distribution according 
to expectation. In all release experiments more recaptures are to be anticipated on the day immediately after release than on subsequent days because of depletion by predation, dispersal or death from other causes. The deficiency of first day recaptures of $f$. edda is therefore

TABLE 4 -continued

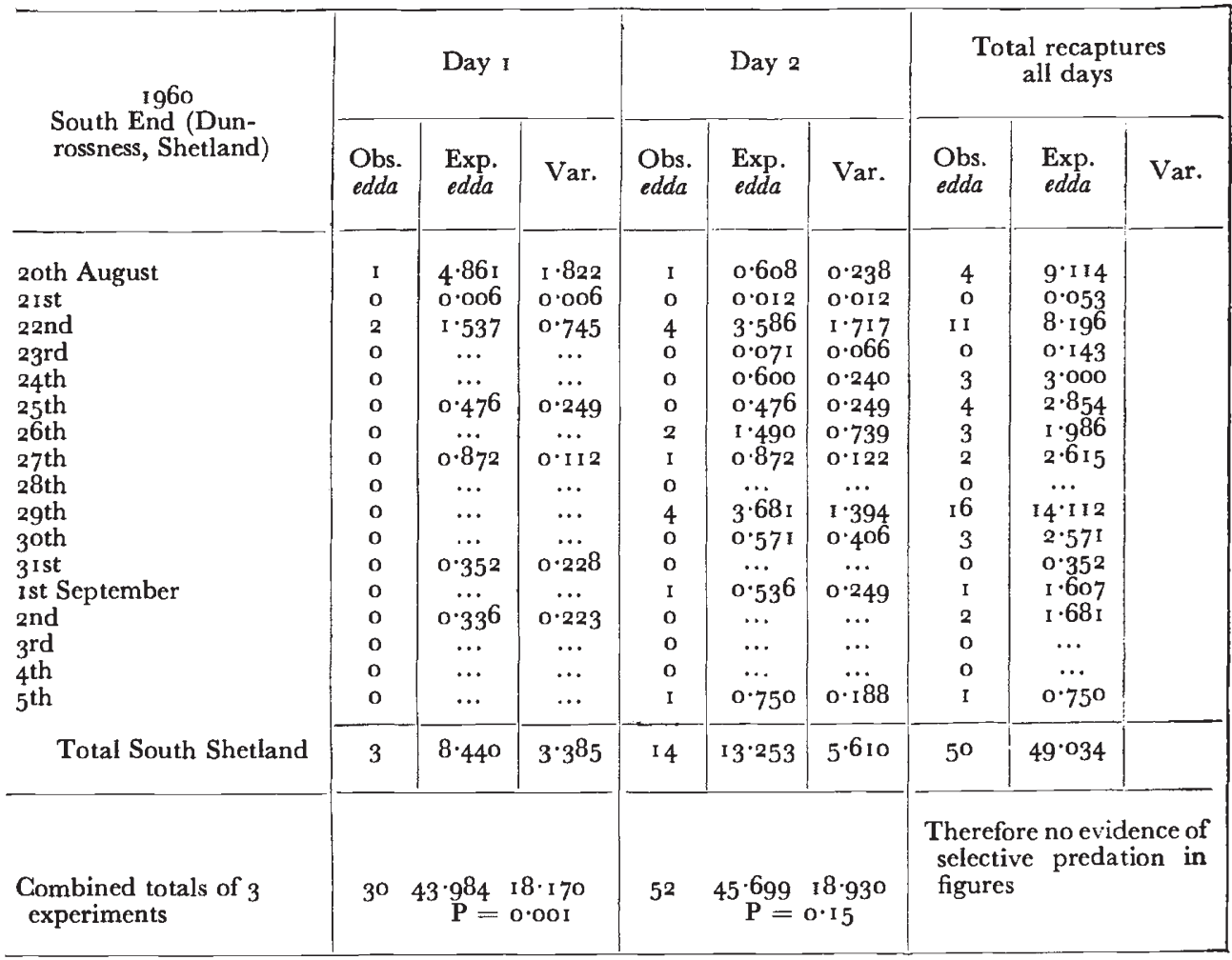

There is no heterogeneity for day I recaptures in the three rclease experiments, nor for day 2. The results can therefore be combined for each day separately.

$$
\begin{array}{ll}
\text { For day I recaptures } & \mathbf{P}=0.001 \\
\text { For day } 2 \text { recaptures } & \mathbf{P}=0.15
\end{array}
$$

Therefore there is a highly significant deficiency of $f . e d d a$ recaptures on day $\mathrm{I}$, compared to f. typica.

quite exceptional and was unexpected. If this departure from expectation was significant it could be of importance.

A second point shown by the histograms is that the total $f$. edda recaptures (assuming equality of release) was greater than that of f. typica.

\section{DISCUSSION 1}

\section{A. Evidence of a behavioural difference in the wild}

A comparison of the proportions of recaptures of the two forms on day $\mathrm{I}$ shows that there is a deficiency of $f$. edda on that day and that the results are homogeneous in all three experiments (table 4). If we 
consider the results of our main experimental work in the north (Unst site 2), we can calculate the mean life-span of both phenotypes after release, for $f$. edda $3.4 \mathrm{I}$ days, for $f$. typica 2.69 days. Assuming these to be constant for each form the expected number of recaptures can be assessed for each day. Hence we can test whether the observed recaptures deviate from the expected. They do not (for edda $\chi_{(13)}^{2}=$ I2.29; for typica $\chi_{(11)}^{2}=\mathrm{I} \cdot 79$ ) except for the edda recaptures for the first day after release on which there is a significant deficiency of recaptures $\left(\chi_{(1)}^{2}=4.85 ; \mathrm{P}=>0.02,<0.05\right)$.

Another method of considering this is to take the total recaptures of both forms on both day I and day 2 and to compare each of these with the number expected along with its variance (tables 4 and $4 a$ ). This method is based upon a technique developed by C. A. B. Smith

TABLE $4(a)$

A comparison of day $I$ and day 2 recaptures from three mark-release-recapture experiments, Shetland, rg6o (summary of table 4)

\begin{tabular}{|c|c|c|c|}
\hline & & Day I & Day 2 \\
\hline Observed edda & . & 30 & $5^{2}$ \\
\hline Expected $e d d a$ & . & $43 \cdot 984$ & $45 \cdot 699$ \\
\hline \multirow[t]{2}{*}{ Variance } & . & $18 \cdot 170$ & 18.930 \\
\hline & & $P=0.00 t$ & $P=0 \cdot 15$ \\
\hline
\end{tabular}

for sibship studies in duodenal ulcers (Clarke et al., I956). In this we have had to make the assumption that the two forms have equal death rates. This is probably near the truth for the first day after release.

When the recaptures for day I and day 2 for all three experiments are considered in this way, the probability of such a deficiency of $f$. edda occurring on the first day by chance is $I$ in Iooo. An explanation of this is unlikely to be accounted for by selective predation in favour of $f$. typica seeing that this did not occur on subsequent days. Furthermore, because of the late hour of release on the previous day, little, if any, predation could have actually taken place. This immediately suggested that our method of sampling was in error and that the absence of edda on day I might reflect a habit difference. It seemed likely in fact that $f$. edda (of local Unst origin) took flight less frequently than $f$. typica (from south Shetland) and that this habit difference was reflected in our trap samples which depended on taking random moths on the wing.

It must here be pointed out that flight in the Shetland Isles in common with other small islands, is a hazardous occupation for most insects, particularly if undertaken near the coast. It will be recalled how on certain islands in other parts of the world apterous species have developed because of this. The average wind strength throughout 
the year in north Shetland is similar to that at the top of Ben Nevis. Nevertheless even under these conditions there must be compensating advantages for flight such as a capacity for finding a mate, an opportunity for feeding or ovipositing on suitable plants, and an assurance of adequate gene-flow. Maximum land dispersal with minimum loss through drowning must in fact conflict in most island species.

We are able to provide further evidence that a habit difference between south Shetland $f$. typica and northern $f$. edda exists. Equal numbers of both forms ( 25 of each) were marked and released into an area of approximately Io square yards at 8 p.m. All the moths took up resting positions after having previously fed. From then till dark I was in a close position to observe them and see that no bird predation took place. The first sign of activity took place at late dusk $(9.55$ p.m. G.M.T. I8th August). Fifteen $f$. typica were seen to fly before I I p.m., but only $5 f$. edda. This could be accounted for because of the greater ease of seeing the light coloured $f$. typica on the wing. However, using a torch a count of I 2 edda to 3 typica $\left(\chi_{1}^{2}=4 \cdot 3\right)$ was made at midnight as they fed or rested on the heather. It was apparent that most of the f. typica had flown. Furthermore, twenty-four hours later on the following evening 5 marked edda were found but no $f$. typica in spite of this form being so much more conspicuous. It is hard to construe these observations in any way other than that under certain conditions $f$. edda takes flight less frequently than $f$. typica, but it must be remembered that the majority of our $f$. typica come from south Shetland.

Independent evidence of a habit difference was obtained by each of us who were responsible for undertaking the daily releases for our main experiments. On being thrown into the air $f$. typica would frequently fly a short distance before settling: $f$. edda was much more lethargic and usually fell to the ground.

Evidence that this habit difference may be associated with the two forms is provided from our sample data from the Tingwall Valley which is situated in the centre of the Mainland barrier zone (Kettlewell and Berry, I96I). In contrast to our usual finding that the frequencies of our samples vary but little from one night to the next, here on the north side of the valley, nightly frequencies fluctuated widely. Heterogeneity by the contingency test is $\chi_{(4)}^{2}=13 \cdot 10$. There is some evidence also that on many nights the frequency of $f$. typica on the north side was inversely proportional to that on the south. Though these observations were made at a period when the species was diminishing in numbers and the samples were therefore small, the most reasonable explanation is that the fluctuations were brought about by a differential flight habit between the two forms. The situation at the Tingwall Valley is that the population to the south is largely composed of wild type. To the north, however, the melanic form rapidly becomes more common. Part of the 196i expedition will be attempting to find out more about the habits of the two forms in this most interesting area. We have, however, already provided 
evidence that different behaviour patterns occur within the species in the wild.

This is the first occasion on which a habit difference has been demonstrated in the wild by mark-release methods in a polymorphic insect. Hovanitz (1948), by other methods demonstrated an activity difference in the white mutant female of Colias butterflies. It is likely that behavioural differences of this kind will be found much more commonly in future and that they will be seen to contribute materially to most balanced polymorphisms.

Mechanism and origin of habit difference. A differential flight activity could be brought about by two distinct mechanisms. Either activity could be controlled by genetic factors or if associated with $f$. edda it could be the direct consequence of the physical difference between black and white bodies. If genetic in origin the behavioural difference could be pleiotropic or it could be controlled by one or more modifying genes which have become linked to the gene responsible for the pigmentation of $e d d a$. Alternatively it could have arisen independently of either form at the opposing ends of a population subject to intensive selection under high wind conditions on small islands and headlands, and where gene-flow was limited between the north and south ends. It has been pointed out that habit differences are more likely to be found in long-standing balanced polymorphisms than in the comparatively recent one of industrial melanism (Kettlewell, I96I).

If decreased flight activity is associated with the melanic $f$. edda, a simple physical phenomenon could account for this as a direct consequence of black colouration. It is necessary for Noctuid moths to vibrate their wings for a considerable period of time before taking flight and this is in order to increase their internal body temperature. The temperature on Unst at night is fairly constant in the month of August and seldom rises above $55^{\circ} \mathrm{F}$. It is possible that on colder nights the heat lost from the black surfaces of $f$. edda is more rapid than the heat produced and that this does not take place in the same way with the light coloured $f$. typica. We intend to check this by using thermo-coupling in the near future.

\section{B. Evidence of a different time of emergence}

If the frequencies of $f$. typica in the daily samples of the wild population on Unst shown in table I are graphed (text-fig. 3) it will be seen that there is a steady increase of this form throughout the period of hatching.

After the end of August it is likely that the majority of $A$. glareosa pupæ have emerged, the population density is in a decline, the samples get smaller and $f$. typica will be disappearing from the population, due to selective predation, more rapidly than $f$. edda. These facts probably account for the drop in the typica frequency after 3 ist August. There are proportionately more $f$. typica in the population in the 
week after peak emergence than before. Williamson (1956) has observed on Fair Isle that $f$. edda (where the phenotype frequency is 30 per cent.) appeared in advance of $f$. typica. Three edda were caught on 4th August 1955, but no $f$. typica were taken until one week

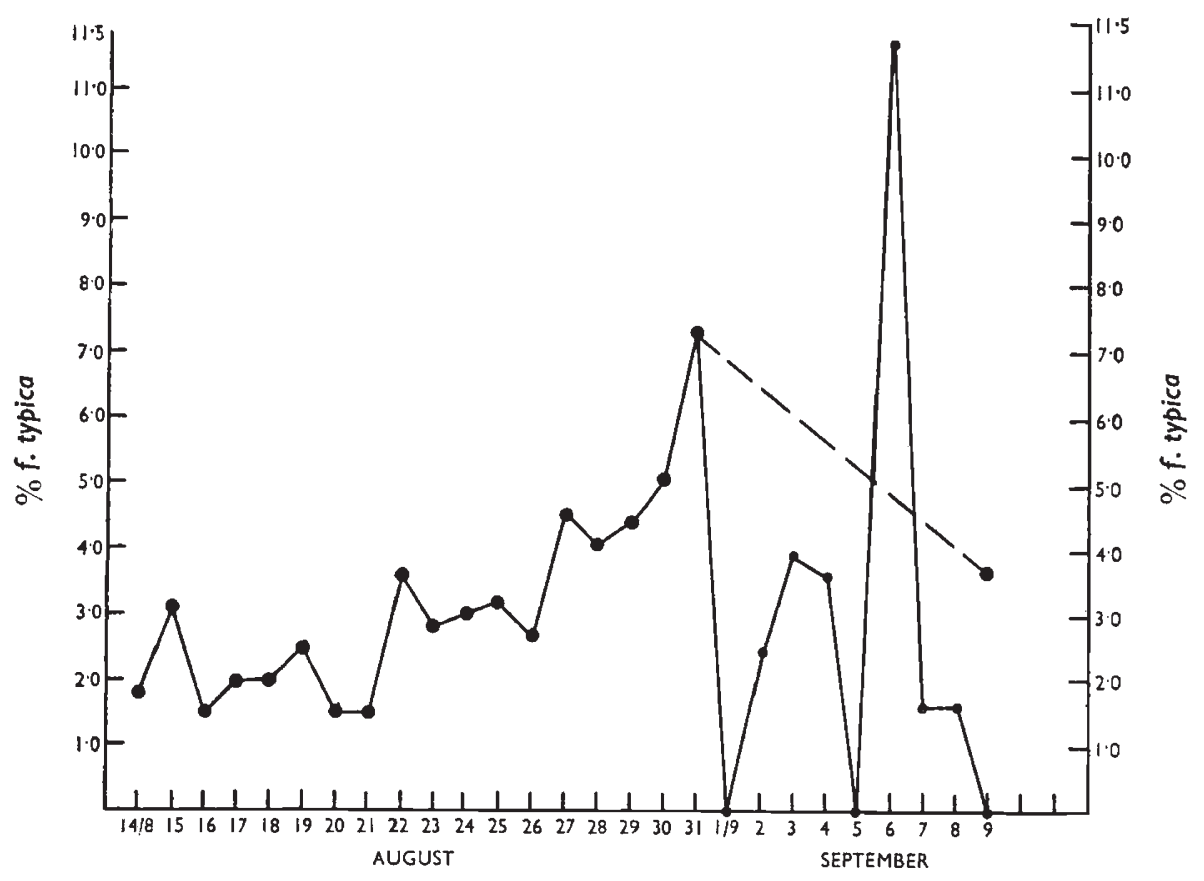

TEXT-FIG. 3.-Graph showing daily percentage of $f$. typica in the wild population on Unst 1960.

later. If the wild type occurs more frequently in samples collected later in the hatching period there are three possible explanations:

I. That the figures directly reflect a deficiency of $f$. typica in the earlier part of the season as the result of selective crepuscular predation which is possible at this time, but not later. Because of the longer hours of darkness which come on rapidly towards the end of August, crepuscular predation may be relaxed. We have been able to show that under conditions of twilight $f$. typica is at a cryptic disadvantage. The average maximum distance that three of us could see $f$. typica in the twilight or full moon, as it fed on heather flowers, was 12 feet: for $f$. edda it was 2 feet.

2. That because of the increased number of hours of darkness late in the season, $f$. typica which may fly more freely than $f$. edda, has greater opportunities than $f$. edda of coming to light traps.

3. That $f$. typica emerges later in the hatching period and that this is controlled genetically and adjusted by selective pressure. Natural selection would favour those typica which hatched later and hence were protected by darkness. 
In regard to explanations $\mathrm{I}$ and 2 our recapture data do not show that a larger proportion of marked f. typica disappeared from our releases in the first half of the experiment than in the second. Nor do they provide evidence that marked $f$. typica were recaptured at light more freely later in the season. In fact we recaptured $6 \cdot 25$ per cent. of marked typica during the first nine days and $\mathrm{I} \cdot 89$ per cent. of our releases during the last ten. It is likely, therefore, that in Unst this seasonal increase in the frequency of typica is also a habit difference and that the majority of $f$. typica pupx hatch at a somewhat later date than those of $f$. edda. Selection for this may have taken place only on those islands which are subjected to intensive bird predation. It is therefore more likely to be observed in populations maintaining a moderately high frequency of $f$. edda.

\section{DISCUSSION 2}

\section{A. Evidence of predation and of differential survival in the wild}

Direct observation on predation. As early as 1876 Buchanan White (1876) recorded that gulls and other birds scouted moths on the wing in twilight in Shetland. More specifically referring to Hepialus humuli (figured Kettlewell, I961a), he states that the white typical forms must be very conspicuous in flight and that the darker forms would be at an advantage under the prevailing conditions. Similar observations have been made by Griffith (1929) who recorded gulls hawking male $H$. humuli for twenty to thirty minutes at dusk. Venables and Venables (1955) also comment on how the gulls appear quite suddenly as soon as the $H$. humuli flight commences and leave after half an hour when it is over. In I 960 we observed the common gull taking on the wing both forms of Arenostola pygmina Haw. which flies in the late afternoon. In 1959 in early August we saw many species of birds feeding on the ground both by day and during the long twilights. We had anticipated that $A$. glareosa would be taken on the wing in the same way as $H$. humuli but saw no evidence of this. To test this we impaled equal numbers of both forms alive on small fish hooks and these were allowed to fly at dusk suspended from very fine nylon stretched out over distances of approximately I oo yards. C. J. Cadbury observed that neither form was predated. He also noted that both forms of $A$. glareos $a$ had whitish hindwings and that they exposed them in flight. This suggested that it was unlikely that aerial predation comparable to that which is known to take place in $H$. humuli was the main selective force at work. If predation in flight was excluded there remained two other vulnerable periods in the course of a day. The moth could be eaten (i) whilst at rest on the ground by day or (ii) whilst feeding on heather flowers or ovipositing in the twilight.

(i) Evidence of A. glareosa predation by day. We constantly saw birds feeding by day on the hillsides through binoculars. The most frequent 
species were the common gull Larus canus L., the wheatear CEnanthe enanthe L., the peewit Vanellus vanellus L., the golden plover Charadrius apricarius L. and the starling Sturnus vulgaris L., the last two species frequently being in flocks. The common gull, up to 50 per cent. of whose diet has been shown by Spärck (1950) to consist of insects, was because of its size likely to be a formidable predator. Breeding common gulls are common throughout the north Shetland Isles but probably less so in the south (Venables, personal communication). They are also augmented by migratory flocks from the north in midAugust (Venables and Venables, 1955).

I therefore decided to shoot a minimum number of gulls during daylight. This was limited to five in all, three in August and two subsequently, both of which had not been feeding and had empty stomachs. Of the three, one was killed on our release ground and the two were half a mile from it. Of the latter, gull I contained $8 \mathrm{~A}$. glareosa, one of which was $f$. typica. Three specimens of Cerapteryx graminis

TABLE 5

Observed feeds per minute of four common gulls, Unst

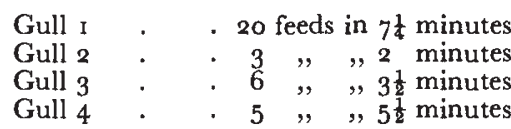

This shows an average of one feed per half minute.

were also among its stomach contents (plate I, fig. I). Gull 2 contained Io $A$. glareosa of which one also was $f$. typica. Two in 18 (I I per cent.) $A$. glareosa were therefore of the white form; the frequency in the local population was $2 \cdot 76$ per cent. The gull which was shot on the releasing ground contained one marked typica previously released by us. On being shot and held upside down the gulls regurgitated the insects which were at the time unrecognisable (plate I, fig. 2). These were cleaned in spirit by Graham Phillips and he was able to show that shortly afterwards both forms were easily identified; the black ventral surface of the abdomen of $f$. edda was distinguishable in the most mutilated specimens. Furthermore he observed the feeding habits of the gulls. They worked individually at a considerable distance apart, and as many as 25 could be seen at a time pacing the short heather on the hillside. He noted the number of feeds per gull per minute for birds which were actually feeding and not preening or resting. Table 5 gives the number of feeds for four common gulls under observation.

As the stomach contents contained by volume 60 per cent. of A. glareosa it is likely that during this period of the year this species is one, if not the main, food source of the common gull. Because of its size, many ounces per day must be eaten by each gull. Their efficiency in finding them astonished us because of the cryptic perfection of the moths, particularly that of $f$. edda. We ourselves succeeded in discovering only one $f$. edda at rest in the wild, though we were able to 
follow many hundreds of released ones to their final resting positions (figured Kettlewell, ig6i). Phillips also examined the stomach contents of wheatear, peewit and starling but no individual Lepidoperta were recognisable. However, under the microscope he showed that the stomach contents contained large quantities of Lepidopterous scales. As $A$. glareosa was the commonest species of moth, it is reasonable to assume that this species contributed to them.

It is certain that throughout the summer a high predation pressure on Lepidoptera is maintained by indigenous birds and that in August and September diurnal predation is increased in North Shetland due to the arrival of migrating flocks. These are unlikely to affect the south Shetland Mainland to the same extent. Under these conditions selective visual predation must be intense, particularly in the north.

(ii) Evidence of A. glareosa predation by night. In 1959 we observed birds, in particular the common gull and wheatear, feeding on the ground until late twilight during the first half of August. It is likely, especially in warm weather, that $A$. glareosa comes up and feeds on heather flowers during the long period of dusk. We have provided evidence (vide ante) that under these conditions $f$. typica would be at a greater cryptic disadvantage. During feeding, both forms frequently sit upside down beneath heather sprigs and, as distinct from $f$. typica, the black ventral surface of the abdomen of $f$. edda serves to make this form less conspicuous. We have as yet no evidence on the degree of crepuscular predation that takes place in this way, but it is our belief that, particularly when full moon falls in the first half of August, it is likely to be heavy. Extensive selective predation in fact may take place both by day and by night in certain years and under certain conditions.

\section{B. Evidence of selective predation from mark-release-recapture data}

We have shown from our day $I$ and day 2 recapture data that a flight habit difference exists between southern $f$. typica and northern edda. This being so it is impossible in our present experiments to differentiate the results of increased dispersal from those of predation. Nevertheless the one must bear a relationship to the other. Under weather conditions such as those experienced on Shetland an increased flight dispersal on small isles and headlands must frequently lead to death from drowning. This situation certainly applies to our releasing site (2) on Unst where the sea lies a few hundred yards to the east. It is therefore worth while considering our recapture data in this light. On Unst a total of 4344 A. glareosa (edda 226o; typica 2084) were marked and released. Of the $f$. typica, approximately 90 per cent. had their origin in south Shetland. In spite of the deficiency in $f$. edda recaptures for day $\mathrm{I}$ the total recaptures were I $32 f$. edda to $95 f$. typica. A chi-squared test for significance cannot, however, be directly applied to these figures because an equal number of releases was not undertaken on each day, but it can be applied to the 
two expecteds, i.e. $123 \cdot 125$ and 103.875 which gives $\chi_{(1)}^{2}=1 \cdot 40$, $\mathbf{P}>0.2<0.3$.

The recapture figures reflect a total of 440 days' survival for $f$. edda in the wild to 256 for $f$. typica. These recapture samples are, however, biased by small numbers of individuals which had survived for a long period of time, and this method of comparison is not therefore strictly valid.

A more refined method is to take the daily recaptures of both forms and compare these with the number expected, along with their variance using Smith's method (Clarke et al., 1956). Table 4 shows that $13^{2} f$. edd $a$ were recaptured and 123.125 expected (a variance of $5^{1} \cdot 426, P=>0.21$ and $\left.<0.22\right)$. There was not therefore a significant excess of $f$. edda recaptured. On the other hand, it suggests a 7 per cent difference in favour of $f$. edda on Unst, though because of the size of the variance this could be as high as 17 per cent advantage or as much as 5 per cent disadvantage. The size of the wild population into which we fed our marked individuals was too large for a significant selective predation difference to be shown by these methods, nor would it be easy to differentiate the dispersal of $f$. typica from selective predation against it.

By contrast the mark-release-recapture results in south Shetland, where no visible evidence of bird predation was seen, showed no differential survival. In releases totalling $2144 \mathrm{~A}$. glareosa (edda 961; (approximately 92 per cent imported from Unst); typica 1 183) observed edda recaptures were $5^{\circ}$, expected $499^{\circ} 034$. In the future therefore the answer to selective bird predation must depend, not on mark-release-recapture data, but on analyses of bird stomach contents, and for this the common gull has been shown to be the most suitable species.

\section{CONCLUSIONS}

The melanic form of Amathes glareosa, $f$. edda, is found at varying frequencies not only throughout Shetland and Fair Isle but also on the Orkneys. The polymor phism is likely therefore to be of considerable age and must be maintained by natural selection. A balance of advantages and disadvantages exists between the wild type and the melanic $f$. edda. By analysis and observation in the field we have been able to provide evidence as to what some of these are. The one gene difference between the two forms is responsible for the substitution of the normal disruptive pattern found throughout its range elsewhere, by a cryptic one of high efficiency for resting on the background of peat which is found throughout the northern half of Shetland. Under conditions of high selective pressures and in latitudes which permit many hours of both daylight and twilight predation, efficient camouflage has a priority over other demands.

Diminished flight activity, which may or may not be associated with $f$. edda, would also conserve loss through wind dispersal on small islands. On the other hand the advantages of flight and the normal 
disruptive pattern in south Shetland, outweigh their disadvantages in north Shetland. This may in part be brought about by a relaxation of bird predation here, in a district of more cultivation, less peat-hag and with fewer small islands and headlands. In particular the common gull and also the vast flocks of immigrant birds from the north which arrive in north Shetland during the months of August and September are less frequent in the south. In Unst (and also Fair Isle), where gull predation is high, there is evidence that the light coloured $f$. typica emerge later in the hatching period than $f$. edda. The longer hours of darkness which rapidly come on later in the season, and the shorter periods of twilight, give more protection to this form, which we have shown is most conspicuous at dusk. Natural selection would therefore favour those f. typica which hatched later.

\section{SUMMARY}

I. By observation and experimentation an attempt has been made to analyse the relative advantages and disadvantages of melanism of non-industrial origin.

2. Mark-release-recapture experiments were conducted in both north and south Shetland on the moth Amathes glareosa Esp. A total of 7232 individuals of both forms were marked and released into the wild populations.

3. On Unst, north Shetland, where heavy predation was shown to take place by the common gull and other birds, a 7 per cent advantage of the melanic form over $f$. typica is indicated from our recaptures, though this is not significant.

4. In south Shetland where no predation was witnessed, there was no differential elimination disclosed from our recapture data.

5. An examination of the stomach contents of the common gull showed that in north Shetland, Lepidoptera, and in particular A. glareosa, formed one if not the chief source of food in the month of August. We have produced some evidence that they predate selectively.

6. A habit difference in which the melanic $f$. edda on Unst exhibit diminished flight activity compared to $f$. typica from south Mainland was demonstrated by three separate methods.

7. We have not yet been able to establish whether this difference in flight activity is associated with the $f$. edda or with the north and south populations.

8. In north Shetland and possibly Fair Isle, the wild type A. glareosa emerge later in the season than $f$. edda. Possible causes of this are discussed.

9. This polymorphism is almost certainly of considerable antiquity. It is maintained by a balance of colour, behavioural (and probably also physiological) differences. In the north efficient camouflage and diminished flight activity outweigh the advantages of the normal disruptive pattern and increased dispersal which are favoured in south Shetland as elsewhere in Britain. 


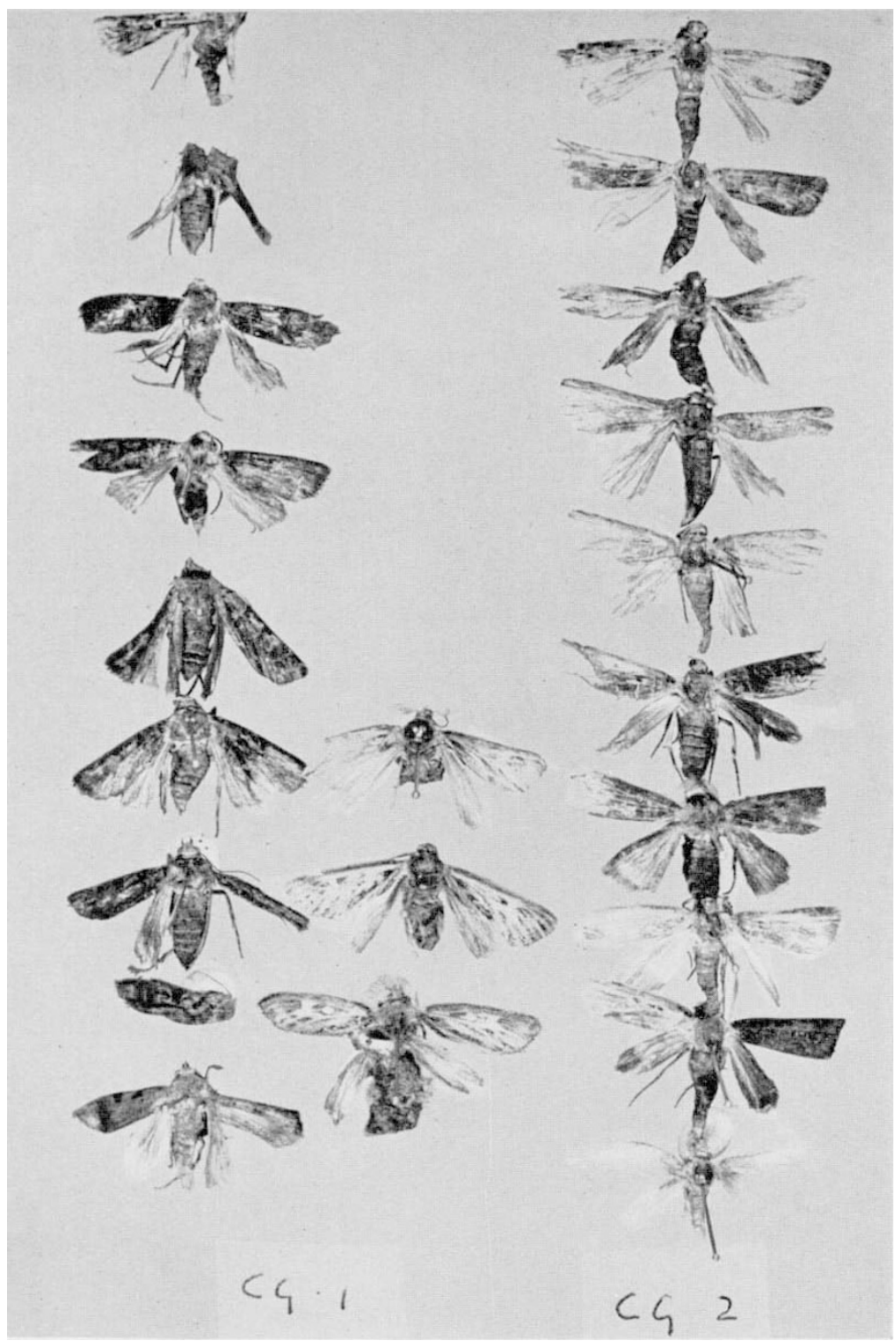

FiG. 1.-Stomach contents taken from two common gulls shot on Unst, 1960.
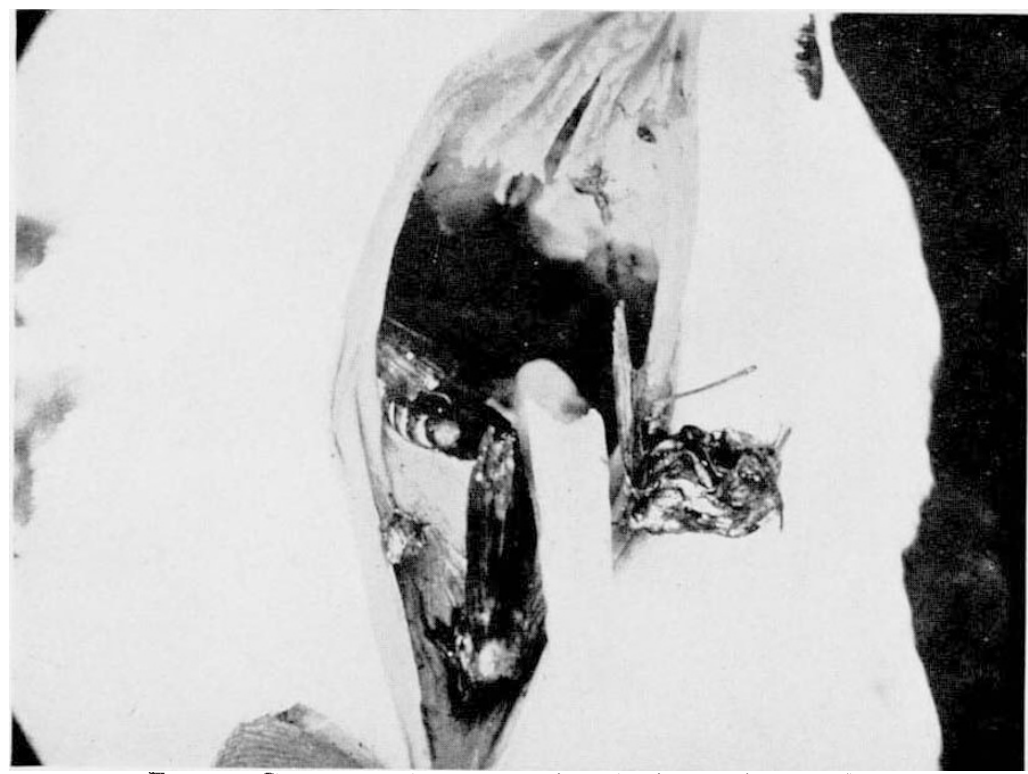

FIG. 2.-Common gull regurgitating A. glareosa, Unst 1960. 


\section{Addendum}

This present work is being undertaken with the object of finding out the uses of melanism in the past. This might throw light on the origin of the present-day industrial melanics. I therefore decided to introduce a number of $f$. edda ova from Shetland of known genefrequency into a circumscribed industrial area and to see if they subsequently behaved as industrial melanics. The oasis of Sutton Park, Birmingham, seemed ideally situated for this. A. glareosa $f$. typica is common here but no melanic forms occur. On I 2th September i 960 we distributed I0,000 ( \pm 500 ) ova with a gene-frequency of approximately 84 per cent. $f$. edda onto the heather slopes of the Park. Due to the dark colouration of the ground it is likely that $f$. edda may have a cryptic advantage; theoretically also diminished flight activity may contain it within the bounds of this limited area. The analogy of Sutton Park to an island is not altogether misplaced. It will be of interest to see whether in the future $f$. edda survives and behaves as an industrial melanic in this area.

Acknowledgments.-I wish to thank the Department of Scientific and Industrial Research whose grant is enabling me to undertake this work in Shetland and also, due to them, to have the assistance of Mr C. J. Cadbury, who has helped me so much. I would also like to thank the Nuffield Foundation. Grants were given to Dr R. J. Berry by the Medical Research Council and to Mr Graham Phillips by Nature Conservancy to enable them to accompany me, and without whose substantial help both in the field and subsequently much information would have been lost. I am particularly indebted to Mr T. Peat and Mr D. Kettlewell who dedicated their vacations to this work and contributed so much. I must acknowledge help so freely given by Dr P. M. Sheppard in regard to statistical analysis-also Dr N. T. J. Bailey and Dr C. A. B. Smith. Dr E. B. Ford and Dr P. M. Sheppard have read the script and for their advice and help I am truly grateful. The photograph, plate I, is by $\mathrm{Mr}$ John Hayward, and histograms and graphs by Miss Christine Court, both of Oxford University. Without the collaboration of a large number of Shetlanders, who showed such keen interest, this work could not have been undertaken.

\section{REFERENCES}

BUChanan white, F. 1876. On melanochroism and leucochroism. Ent. Mo. Mag., $13,148-149$.

CLARKE, C. A., WYN EDWARDS, J., HADDOCK, D. R. W., HOWES-EVANS, A. W., McCONNELL, R. B., AND SHEPPARD., P. M. 1956. ABO blood groups and secretor character in duodenal ulcer. Brit. Med. 7., 2, 725 .

DOWDESWELL, W. H., FISHER, R. A., AND FORD, E. B. 1940. The quantitative study of populations in the Lepidoptera. Ann. Eugen., ro, 123-136.

GRIFFITH, A. W. 1929. British Ornithological Club Bulletin, 101.

HOVANITZ, w. 1948. Differences in the field activity of two female colour phases of Colias butterflies at various times of the day. Centr. Lab. Vertebr. Biol. Univ. Mich., $4^{I}$, I-37.

Kettlewell, H. B. D. 1961: The phenomenon of Industrial Melanism in Lepidoptera. Ann. Rev. Ent., 6, 245-262.

Kettlewell, н. B. D., AND berry, R. J. 1961. The study of a cline. Heredity, r6, 403-4 ${ }^{1} 4$.

$2 \mathrm{E}$ 
SPÄRCK, R. I950. Proceedings of the Xth International Ornithological Congress, $588-591$. SPENCE, D. H. N. 1957. Studies on the vegetation of Shetland. I. The serpentine debris vegetation in Unst. F. Ecol., 45, $917-945$.

venables, L. S. V., AND venABles, w. M. 1955. Birds and Mammals of Shetland, 307-308.

Williamson, к. r956. Birds and lepidoptera in anticyclonic airstreams. Ent. Rec., $68,95-97$. 